\title{
EMERGENCE AND EARLY DEVELOPMENT OF SEEDLINGS OF Mimosa ophthalmocentra Mart. ex Benth.) IRRIGATED WITH BRACKISH WATER
}

\author{
EMERGENCIA E DESENVOLVIMENTO INICIAL DE PLÂNTULAS DE JUREMA- \\ IMBIRA, Mimosa ophthalmocentra Mart. ex Benth, IRRIGADAS COM ÁGUA \\ SALOBRA
}

\section{Caio César Pereira LEAL ${ }^{1}$; Salvador Barros TORRES ${ }^{2}$; Narjara Walessa NOGUEIRA ${ }^{1}$; Rômulo Magno Oliveira de FREITAS ${ }^{1}$; Raul Martins de FARIAS ${ }^{3}$}

1. Doutorando do Programa de Pós-Graduação em Fitotecnia, Universidade Federal Rural do Semi-Árido, Mossoró, RN, Brasil. caioleal3@ hotmail.com; 2. Professor Colaborador, Doutor, Universidade Federal Rural do Semi-Árido e Pesquisador da Empresa de Pesquisa Agropecuária do Rio Grande do Norte, Mossoró, RN, Brasil; 3. Engenheiro Agrônomo, Universidade Federal Rural do SemiÁrido, Mossoró, RN, Brasil.

\begin{abstract}
The species Jurema-imbira (Mimosa ophthalmocentra) is typical of the Caatinga of Northeast Brazil and has medicinal properties; besides being also used by timber industry. The study aimed at assessing effects of irrigation water salinity on emergence and early development of seedlings of jurema-imbira (Mimosa ophthalmocentra Mart. ex Benth.). For this, seeds were manually extracted from the pods of matrix plants and sown under greenhouse conditions in polystyrene trays and irrigated with brackish solutions calibrated to electrical conductivity of $1.5,2.5,3.5$, 4.5 and $5.5 \mathrm{dS} \mathrm{m}^{-1}$; and a treatment with tap water with salinity level of $0.5 \mathrm{dS} \mathrm{m}^{-1}$ was used as control. The experiment was conducted in October 2013. Parameters assessed were: seedling emergence, emergence speed, seedling height, root length, stem diameter, dry mass of shoots, dry mass of roots and total dry mass of seedling. A completely randomized design was used with six treatments, and four replications each consisting of of 25 seeds per treatment. Adjustment of nonlinear and polynomial regression curves, which was used to estimate behavior of variables assessed was performed with aid of software Sigmaplot ${ }^{\circledR}$. Salinity negatively affects all variables directly proportional to its increase in the irrigation water, with the greatest seedling development at a dose of $1.5 \mathrm{dS} \mathrm{m}^{-1}$.
\end{abstract}

KEYWORDS: Mimosa ophthalmocentra. Salt stress. Salinity. Plant performance.

\section{INTRODUCTION}

The hardwood tree Mimosa ophthalmocentra Mart. ex Benth., that is commonly known in Brazil as jurema-imbira, belongs to the family Fabaceae (Leguminosae) and subfamily Mimosoideae; and besides medicinal properties this species also has high potential use by the timber industry for presenting a thin bark, an almost smooth wood, with grayish-brown coloration and yellowish lenticels, and with density ranging from $0.82 \mathrm{~g} \mathrm{~cm}^{3}$ to $1.06 \mathrm{~g} \mathrm{~cm}^{3}$ (FIGUERÔA et al., 2005; SILVA et al., 2011). The roots of jurema-imbira are widely used in the countryside of Brazilian Northeastern Region to prepare the wine-of-jurema, a beverage much used by several indigenous tribes on mystical-religious ceremonies; besides be amply used by the native population of region as traditional medicine for treating wounds, and preventing inflammations, bronchitis, and cough (AGRA et al., 2007). For possessing such characteristics, and inasmuch as this hardwood tree is typical of biome Caatinga, the species is very important in the process of recovering of Savannah vegetation of Northeastern Brazil; once that according to Amorim et al. (2002) it is important stimulating such reforestation with perennials fully adapted to the region. However, it is very important knowing the factors that affect the development of these species in intensive cultivations.

Arid and semiarid regions, such as the Caatinga, whose climate is characterized by extensive periods of drought with high temperatures, constitute about $40 \%$ of total surface of the earth, which limits world agricultural production (FREIRE et al., 2010). According to these same authors, in addition to climatic factors soil salinity has have been higher in recent decades due to incorrect or improper use of farming techniques, such as excessive fertilization and/or irrigation with brackish water that is unfit for agriculture; thereby transforming the areas with soil previously fertile and productive into degraded and arid areas. The increase on soil salinity by the use of brackish water, as well as the excessive application of chemical fertilizers is associated to reduction on productive potential of soil to the point of limiting seed germination (BETONI et al., 2011). Therefore, it is very important to know the behavior and tolerance of each of these plant species in relation to soil salinity in which these plants will be grown; and one of the best methods for determining such 
tolerance is to study germination of the seeds of these species in substrates with different salt concentrations and compare them with germination obtained in substrates with normal salinity (OLIVEIRA et al., 2007). When seeds are germinated on a substrate with high sodium chloride concentration initially it is observed a decrease in water absorption, followed by reduction on percentage and germination speed, and finally the toxic effect of salinity of substrate on development of embryo may be observed (SIVRITEPE et al., 2003).

Salinity tolerance is generally regarded as the biomass percentage produced by plants grown under high salinity conditions compared to biomass percentage produced by plants grown under normal salinity conditions over a given time period. However, such tolerance may also be assessed in terms of survival of plants grown under salt stress, which is quite suitable to perennial species, but for annual species, especially for extensive or horticultural crops, the rate of biomass production is much more useful; once it allows correlating productivity of crops with soil salinity levels (MUNNS, 2002).

Given the importance of salinity effect on cultivated plants, several studies are currently being conducted on this topic. As examples it can be cited the studies with: Myracroduon urundeuva Fr. All. (OLIVEIRA et al., 2007); with Gliricidia sepium (Jacq.) Steud. (FARIAS et al., 2009); with Zizyphus joazeiro Mart. (LIMA and TORRES, 2009); with Mimosa tenuiflora (Willd.) Poiret. (BAKKE, 2006); with Mimosa caesalpinaefolia Benth. (BARRETO, 2010) and (RIBEIRO et al., 2008; with Leucaena leucocephala (Lam.) R. de Wit (FREIRE et al., 2010); with Jatropha curcas L. (OLIVEIRA et al., 2010); with Guazuma ulmifolia Lam. (BETONI et al., 2011); with Delonix regia (Bojer ex Hook.) Raf. (NOGUEIRA et al., (2012); and with Albizia lebbeck (L.) Benth. (LIMA et al., 2015).

Based on the foregoing, this study aimed at assessing the irrigation effect with brackish water on emergence and on early seedlings development of jurema-imbira.

\section{MATERIAL AND METHODS}

The experiment has been carried out under greenhouse environmental conditions, in the Department of Plant Sciences, of Universidade Federal Rural do Semi-Árido (UFERSA - from its Portuguese acronym to Rural Federal University of Semi-Arid), Central Campus, municipality of Mossoró, state of Rio Grande do Norte , Brazil
( $5^{\circ} 11^{\prime}$ South; $37^{\circ} 20^{\prime}$ West; $16 \mathrm{~m}$ altitude), In the Month of October 2013.

Seeds used in the experiment were originated from pods collected from matrix plants of jurema-imbira available in the municipality of Mossoró. Seeds were extracted and cleaned by hand, placed to dry under a shaded environment, and homogenized soon after drying process. As seeds of this species present tegumental dormancy, and following recommendations of Fowler and Bianchetti (2000), at the opposite the micropyle, a cut with scissors was made in testa of each seed.

The experiment has been conducted on a completely randomized experimental design, with six treatments (five different salt concentration levels + control) and four replications of 25 seed each, to each treatment. Treatments consisted of five different salt concentrations, calibrated to electrical conductivity of $1.5,2.5,3.5,4.5$ and $5.5 \mathrm{dS} \mathrm{m}^{-1}$; and control treatment consisted of tap water containing a considered normal salt concentration $\left(0.5 \mathrm{dS} \mathrm{m}^{-1}\right)$. For obtaining desired saline concentrations different amounts of $\mathrm{NaCl}$ (regular iodized salt) were added to same type of tap water used in the control treatment. Seeding has been performed in polystyrene trays, each containing 128 individual cells, which were filled with $40 \mathrm{~cm}^{3}$ of a substrate composed of coconut fiber and then received only one seed of jurema-imbira in each of one them. Irrigation was performed once a day with a mean volume of $250 \mathrm{ml}$ per replicate by applying each of the previously prepared saline solutions for every treatment.

Percentage of seedling emergence, which was obtained through daily assessments and held until the fifteenth day was computed, based on results obtained in these assessments; and only those seedlings with cotyledons exposed above soil surface were considered emerged. The other parameters assessed were obtained as follow: 1 emergence speed was determined by equation proposed by Edmond and Drapala (1958); 2 seedling height and root length were measured from soil line until apex of apical meristem, and from soil line until root tip; 3 - stem diameter was obtained by measuring the base of each hypocotyl circumference with aid of a digital caliper; and 4 total dry mass of seedlings was obtained by summing the dry mass obtained for 10 seedlings per plot, which after drying in a forced air circulating drying oven, at $65{ }^{\circ} \mathrm{C}$, until reaching constant weight, were weighed on an analytical balance with $0.0001 \mathrm{~g}$ precision divided by number of seedlings assessed. 
Results obtained were firstly subjected to exploratory analysis for assessing assumptions of normality of residues, homogeneity variance of treatments, and additivity of the model, to allow applying the ANOVA. Means were compared by Tukey test $(\mathrm{p} \leq 0.05)$ using the software SISVAR 5.3 (FERREIRA, 2011). To adjust nonlinear regression and polynomial curves, used to estimate behavior of parameters assessed in function of salt concentration in irrigation water, it was used the software Sigmaplot $^{\circledR}$.

(A)

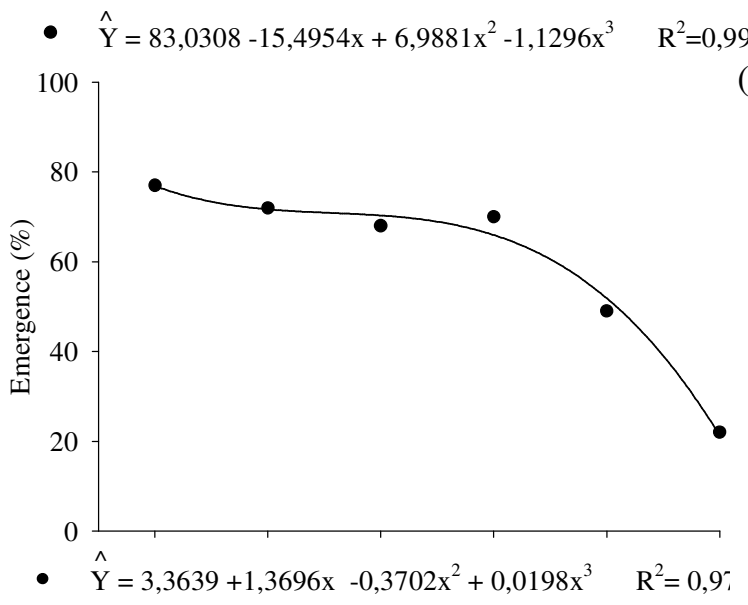

(C)

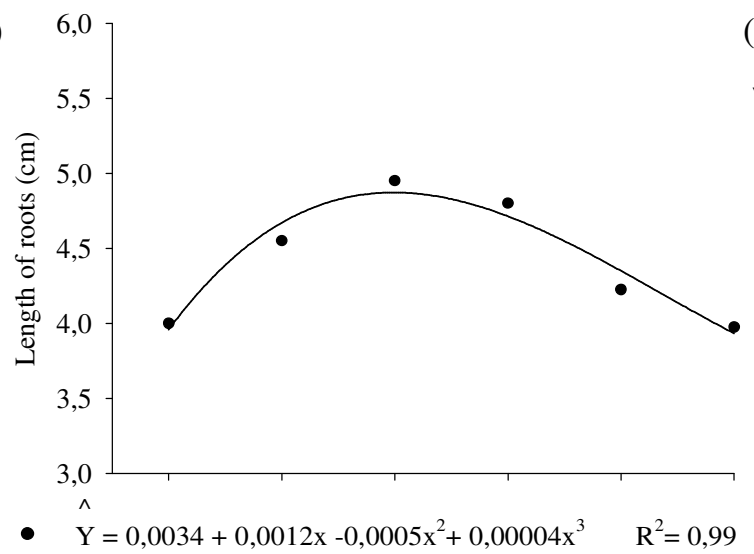

(E) 0,0050

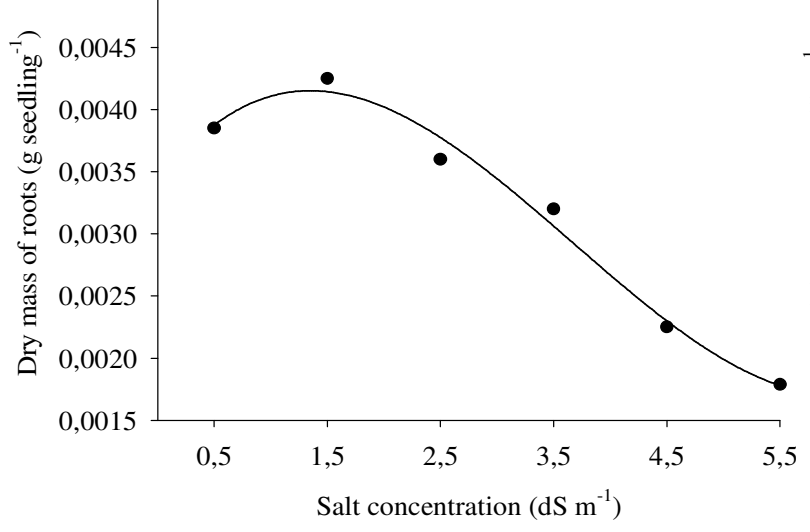

\section{RESULTS AND DISCUSSION}

According to results obtained in the experiment it was verified that there was statistically significant difference only among values found for percentage and speed of emergence, root length, and dry mass of shoots and roots and total dry mass. However, for values found for shoot length and stem seedling diameter at soil line, differences were not statistically significant (Figure 1).

(B) 4,4

- $\hat{\mathrm{Y}}=3,1556+0,2934 \mathrm{x}-0,1286 \mathrm{x}^{2}+0,0255 \mathrm{x}^{3} \quad \mathrm{R}^{2}=0,99$

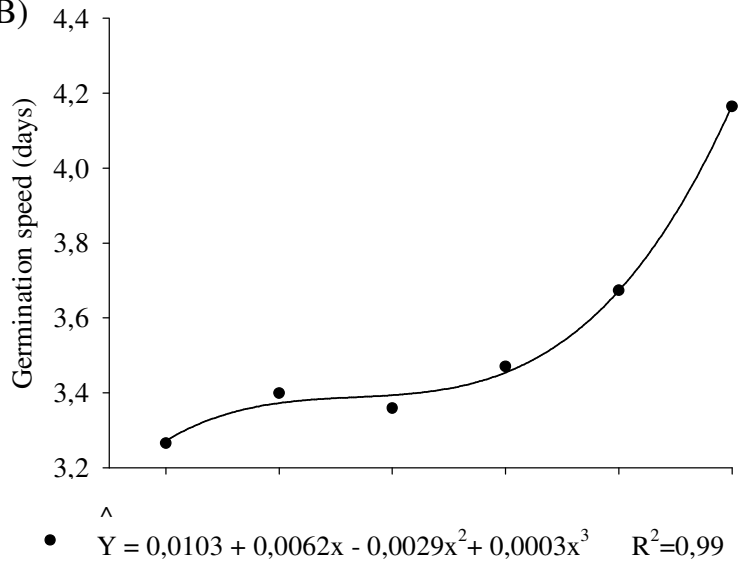

(D) 0,018
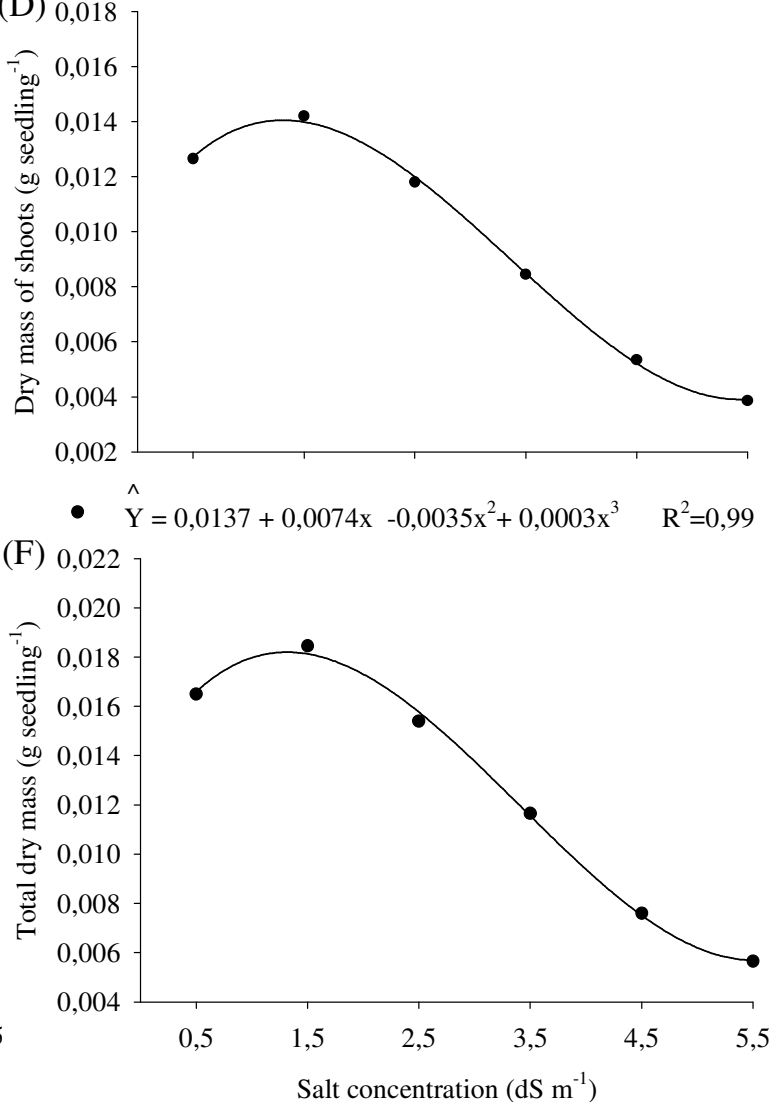

Figure 1: Polynomial nonlinear regression curves computed to: percent emergence (A); emergence speed (B), length of roots (C), dry mass of shoots (D), dry mass of roots (E), and total dry mass (F) of seedlings of jurema-imbira (Mimosa ophthalmocentra Mart. ex Benth.) irrigated with brackish solutions, with salt concentrations ranging from $0.5 \mathrm{dS} \mathrm{m}^{-1}$ to $5.5 \mathrm{dS} \mathrm{m}^{-1}$. 
The highest percent emergence was observed in treatment where seedlings were irrigated with brackish water solution with $\mathrm{NaCl}$ in electrical conductivity of $0.5 \mathrm{dS} \mathrm{m}^{-1}$. However, there was a small decrease on emergence percentage when seedlings were irrigated with brackish water solution with electrical conductivity of $\mathrm{NaCl}$ higher than $1.5 \mathrm{dS} \mathrm{m}^{-1}$. Percent emergence has remained stable until the electrical conductivity of $3.5 \mathrm{dS} \mathrm{m}^{-1}$; however, there was a very sharp decrease with the application of brackish water solution at $\mathrm{NaCl}$ in electrical conductivity of $5.5 \mathrm{dS} \mathrm{m}^{-1}$ that was treatment presenting the smallest values for this variable (Figure 1A).

Stability of values obtained for emergence percentage, until $\mathrm{NaCl}$ concentration of $3.5 \mathrm{dS} \mathrm{m}^{-1}$ in the brackish solution suggests this species presents a moderate tolerance to salinity. Similar results were found by Nogueira et al. (2012), with flamboyant seedlings in solutions of $\mathrm{NaCl}$ concentrations of $0.5,1.5,3.0,4.5$ and $6.0 \mathrm{dS} \mathrm{m}^{-1}$ found that this species is tolerant to salinity of irrigation water until the concentration of $4.5 \mathrm{dS} \mathrm{m}^{-1}$ $\mathrm{NaCl}$. These authors have also observed that statistical difference among values obtained for different treatments studied was significant only at maximum salt concentration of $6.0 \mathrm{dS} \mathrm{m}^{-1}$. Likewise Freitas et al. (2010), with seedlings of Brazilian ironwood (Caesalpinia ferrea Mart.) have observed reduction on percent emergence, which was proportional to increasing salinity levels in irrigation water, with greater evidence of such reduction in the $\mathrm{NaCl}$ concentration of $3.0 \mathrm{dS} \mathrm{m} \mathrm{m}^{-1}$; thereby demonstrating that such species also presents moderate tolerance to salinity, being considered a glicophyte (MAYER; POLJAKOFF-MAYBER, 1989).

However, Guedes et al. (2011) with seeds of floss-silk tree (Ceiba speciosa (A. St.-Hil.) Ravenna), irrigated with brackish water solutions at different $\mathrm{NaCl}$ concentrations [0 (control), 1.5, 3.0, 4.5 and $6.0 \mathrm{dS} \mathrm{m}^{-1}$ ] and germinated under different fixed temperatures $\left(25^{\circ} \mathrm{C}, 30{ }^{\circ} \mathrm{C}\right.$ and $\left.35^{\circ} \mathrm{C}\right)$ and alternating temperatures (between $20^{\circ} \mathrm{C}$ and $30^{\circ} \mathrm{C}$ ) have observed that in all temperatures studied, germination was reduced when $\mathrm{NaCl}$ concentration in the irrigation water was increased. These same authors have also observed that the highest germination percentage $(86 \%, 68 \%$ and $75 \%$, respectively) were achieved for seeds germinated under fixed temperatures in the zero salinity level, and that from this salinity level germination was negatively affected; reaching values of $38 \%$ and $14 \%$ germination under the fixed temperatures of 25 and $30{ }^{\circ} \mathrm{C}$, respectively, and $35 \%$ germination when seeds were germinated under alternating temperatures at salt concentration level of $6.0 \mathrm{dS} \mathrm{m}^{-}$ 1 .

Such difference on percent germination obtained when seeds were germinated under higher levels of irrigation water salinity could have been due to the fact that by absorbing brackish water the seeds have also absorbed excess of sodium chloride, which once dissolved in the brackish solution has caused toxicity, as well as physiological disturbances in the seeds; thereby causing a decrease of their germinative potential (FERREIRA, 1997). However, it should be emphasized that despite reduction in the values obtained for emergence percentage of jurema-imbira seedlings, it is possible stating this species is able to grow on more saline soils; and thereby be sorted as moderately tolerant to salinity.

The Polynomial nonlinear regression curves for the parameter velocity emergency had a similar behavior to the regression curve for the parameter percentage of emergency (Figure 1B).

The polynomial nonlinear regression curve for emergence speed has had a similar behavior to the regression curve for percentage emergence (Figure 1B). As shown on this figure the smallest values for these two parameters were found in the treatment where the brackish water solution was applied at concentration of $0.5 \mathrm{dS} \mathrm{m} \mathrm{m}^{-1} \mathrm{NaCl}$. However, for the values above $1.5 \mathrm{dS} \mathrm{m}^{-1}$ there was a small decrease in values obtained for these parameters, which have remained stable until salt concentration of $3.5 \mathrm{dS} \mathrm{m}^{-1}$. Nevertheless, there was a drastic decrease in these values from the concentration of $5.5 \mathrm{dS} \mathrm{m}-1 \mathrm{NaCl}$ in the brackish water solution (Figure1B).

As examples may be cited the studies of Souza Filho (2000), which were conducted with Leucaena seeds; those of Ribeiro et al. (2008) with seeds of Mimosa caesalpinaefolia Benth; and those of Freitas et al. (2010), carried out with seeds of Caesalpinia ferrea Mart.w, here the gradual increase on salt concentration in irrigation solution has caused reduction on seed germination speed. Such reduction may be attributed to increases on levels of sodium chloride concentration in soil caused by increased amount of salts dissolved in irrigation water; thereby inducing a reduction on osmotic potential of the seeds, and consequently a decrease on water absorption; thus impairing their physiological processes and reducing emergence speed of seedlings (KASHEM et al., 2000).

The highest value obtained for length of roots was found in treatment where plants were irrigated with brackish water solution containing 
$\mathrm{NaCl}$ at concentration of $2.5 \mathrm{dS} \mathrm{m}^{-1}$ (Figure 1C); thereby demonstrating that such species is able to develop a normal root system and deepen its main root even in more saline soils, which is primordial for development of jurema-imbira seedlings on soils with higher salinity than normal $\left(0.5 \mathrm{dS} \mathrm{m}^{-1}\right)$.

However, for dry matter parameter (aerial part, roots, and total dry mass) the highest values were obtained in treatment where the brackish water solution was used at $\mathrm{NaCl}$ concentration of $1.5 \mathrm{dS}$ $\mathrm{m}^{-1}$. Nevertheless, in treatment where $\mathrm{NaCl}$ concentration in the irrigation water was higher than such value, there have been a decrease on dry mass accumulation in shoots and roots of seedlings; and the lowest value for this parameter was found in treatment where $\mathrm{NaCl}$ concentration was maximum (6.0 dS m $\mathrm{m}^{-1}$ ) (Figures 1D, 1E, and 1F).

Likewise, Oliveira et al. (2009) who working with seedlings of Drumstick tree (Moringa oleifera Lam.), irrigated with brackish water at $\mathrm{NaCl}$ concentrations between 0 and $5.0 \mathrm{dS} \mathrm{m}{ }^{-1}$ under greenhouse environmental conditions have observed that values obtained for dry matter accumulation in these seedlings were reduced and with values statistically different when salinity level of irrigation water was gradually increased. However, Nogueira et al. (2012) in a similar study performed with brackish water with salt concentrations ranging between 0 and $6.0 \mathrm{dS} \mathrm{m} \mathrm{m}^{-1}$, and by using flamboyant seeds have observed that there were no statistical differences among values obtained in treatments where irrigation with brackish water was applied to the seedlings with sodium chloride concentrations of $0.5,1.5$ and $3.0 \mathrm{dS} \mathrm{m}^{-1}$. These authors have also observed that decrease on dry matter accumulation has occurred from the $\mathrm{NaCl}$ concentration of $4.5 \mathrm{dS}$ $\mathrm{m}^{-1}$; and that the lowest value for this variable was found in treatment where salt concentration in irrigation solution was $6.0 \mathrm{dS} \mathrm{m} \mathrm{m}^{-1}$.

Similarly, Silva et al. (2005) in a study carried out with seedlings of Cnidoscolus phyllacanthus (Müll. Arg.) Pax \& L. Hoffm. irrigated with brackish water with salt concentrations between $1.0 \mathrm{dS} \mathrm{m}^{-1}$ and $6.0 \mathrm{dS} \mathrm{m}^{-1}$ have also observed a reduction of $63.40 \%$ in shoots dry mass when these seedlings were irrigated with brackish water at salt concentration between the lowest and the highest studied level.

On studies carried out with Moringa oleifera Lam. tree seedlings, Miranda et al. (2007) observed that with gradual increase in salt concentration in irrigation water (from 0 to $150 \mathrm{~mol}$ $\mathrm{m}^{-1}$ ) there was a proportional decrease in the dry matter accumulation in roots of these seedlings; and that despite the salinity level for such species to be suitable, only at a maximum salt concentration in soil of until a maximum of $30 \mathrm{~mol} \mathrm{~m}^{-1}$, irrigation water applied with salt concentration of $60 \mathrm{~mol} \mathrm{~m}^{-1}$ has not exerted toxic effects on the root system or on the normal development of seedlings, what was also found in this study by the irrigation of seedlings with brackish water with a sodium chloride concentration of $1.5 \mathrm{dS} \mathrm{m}^{-1}$.

Plants presenting low tolerance to higher soil salinity levels, both for germination of their seeds as well as for the various stages of their development are termed glycophytes, and plants that have developed mechanisms to adapt to such soil salinity conditions are denominated halophytes (MAYER; POLJAKOFF-MAYBER, 1989). Therefore, for presenting moderate tolerance to soil salinity levels until salt concentration of $1.5 \mathrm{dS} \mathrm{m}^{-1}$ applied within this study via irrigation water, the hardwood tree jurema-imbira can be sorted as a glycophyte species.

\section{CONCLUSION}

The salinity interfered negatively in all variables of proprocional way to their increase in irrigation water seedling jurema-imbira, and the further development of these obtained in $\mathrm{NaCl}$ electrical conductivity of $1.5 \mathrm{dS} \mathrm{m}-1$.

RESUMO: A espécie Jurema-imbira é típica do bioma Caatinga e, além de possuir propriedades medicinais, também é utilizada pela indústria madeireira. O estudo teve como objetivo avaliar o efeito da salinidade da água de irrigação na emergência e desenvolvimento inicial de plântulas de jurema-imbira. Para isso, sementes foram extraídas manualmente de vagens oriundas de plantas matrizes e semeadas em bandejas de poliestireno expandido, em condições ambientais de casa de vegetação, e irrigadas com soluções salobras calibradas para condutividade elétrica de 1,$5 ; 2,5 ; 3,5$; 4,5 e $5,5 \mathrm{dS} \mathrm{m}^{-1}$. Como testemunha foi utilizada água de torneira $\left(0,5 \mathrm{dS} \mathrm{m}^{-1}\right)$. O experimento foi conduzido no mês de outubro de 2013. Os parâmetros avaliados foram: porcentagem e velocidade de emergência; altura da plântula; comprimento da raiz; diâmetro do caule; massa seca da parte aérea, massa seca da raiz e massa seca total. O delineamento estatístico inteiramente casualizado foi utilizado com seis tratamentos e quatro repetições de 25 sementes cada, para cada tratamento. O ajuste das curvas de regressões não lineares e polinomiais, usadas para estimar o comportamento das características avaliadas, foi realizado com o auxílio do software Sigmaplot ${ }^{\circledR}$. A salinidade interferi negativamente em 
todas as variáveis avaliadas de forma proprocional ao seu aumento na água de irrigação das plântulas de jurema-imbira, sendo o maior desenvolvimento destas obtido na concentração de $\mathrm{NaCl}$ de $1,5 \mathrm{dS} \mathrm{m}^{-1}$.

PALAVRAS-CHAVE: Mimosa ophthalmocentra. Estresse salino. Salinidade. Desempenho de planta.

\section{REFERENCES}

AGRA, M. F.; BARACHO, B. S.; BASÍLIO, I. J. D.; NURIT, K.; COELHO, V. P. BARBOSA, D. A. Sinopse da flora medicinal do cariri paraibano. Oecologia Brasiliensis, Rio de Janeiro, v. 11, n. 3, p. 323-330, 2007.

AMORIM, J. R. A.; FERNANDES, P. D.; GHEYI, H. R.; AZEVEDO, N. C. Efeito da salinidade e modo de aplicação da água de irrigação no crescimento e produção de alho. Pesquisa Agropecuária Brasileira, Brasília, v. 37, n. 2, p. 167-176, 2002. http://dx.doi.org/10.1590/S0100-204X2002000200008

BAKKE, I. A.; FREIRE, A. L. O.; BAKKE, O. A.; ANDRADE, A. P.; BRUNO, R. L. A. Water and sodium chloride effects on Mimosa Tenuiflora (WILLD.) poiret seed germination. Revista Caatinga, Mossoró, v. 19, n. 3, p. 261-267, 2006.

BARRETO, H. B. F.; FREITAS, R. M. O.; OLIVEIRA, L. A. A.; ARAUJO, J. A. M.; COSTA, E. M. Efeito da irrigação com água salina na germinação de sementes de sábia (Mimosa caesalpiniifolia Benth). Revista Verde de Agroecologia e Desenvolvimento Sustentável, Mossoró, v. 5, n. 3, p. 125-130, 2010.

BETONI, R.; SCALON, S. P. Q. E; MUSSURY, R. M. Salinidade e temperatura na germinação e vigor de sementes de mutambo (Guazuma ulmifolia lam.) (sterculiaceae). Revista Árvore, Viçosa, v. 35, n. 3, p. 605 616, 2011.

EDMOND, J. B.; DRAPALA, W. J. The effects of temperature, sandand soil, and acetone on germination of okra seeds. Proceedings of American Society of Horticultural Science, v. 71, p. 428-434, 1958.

FARIAS, S. G. G.; FREIRE, A. L. O.; SANTOS, D. R.; BAKKE, I. A.; SILVA, R. B. Efeitos dos estresses hídrico e salino na germinação de sementes de gliricídia [Gliricidia sepium (Jacq.) Steud.]. Revista Caatinga, Mossoró, v. 22, n. 4, p. 152-157, 2009.

FERREIRA, D. O. Sisvar: a computer statistical analysis system. Ciência e Agrotecnologia, Lavras, v. 35, n. 6, p. 1039-1042, 2011.

FERREIRA, P. A. Aspectos físico-químicos do solo. In: GHEYI, H. R.; QUEIROZ, J. E.; MEDEIROS, J. F. Manejo e controle da salinidade na agricultura irrigada. Campina Grande: UFPB/SBEA, 1997. p.37-67.

FIGUEIRÔA, J. M.; PAREYN, F. G. C.; DRUMOND, M.; ARAÚJO, E. L. Madeireiras. In: SAMPAIO, E. V. S. B.; PAREYN, F. G. C.; FIGUEIRÔA, J. M. E.; SANTOS JÚNIOR, A. G. (ed.). Espécies da flora nordestina de importância econômica potencial. Recife: Associação Plantas do Nordeste (APNE), 2005. p.101-1330

FOWLER, J. A. P.; BIANCHETTI, A. Dormência em sementes florestais. Colombo: Embrapa Florestas, 2000. 27p. (Documento 40).

FREIRE, A. L. O.; RODRIGUES, T. J. D.; MIRANDA, J. R. P. Crescimento e nutrição de plantas de leucena (Leucaena leucocephala (Lam.) R. de Vit) sob salinidade. Revista Caatinga, Mossoró, v. 23, n. 4, p. 1-6, 2010.

FREITAS, R. M. O.; NOGUEIRA, N. W.; OLIVERA, F. N.; COSTA, E. M.; RIBEIRO, M. C. C. Efeito da irrigação com água salina na emergência e crescimento inicial de plântulas de jucá. Revista Caatinga,

Mossoró, v. 23, n. 3. P. 54-58, 2010. 
GUEDES, R S.; ALVES, E. U.; GALINDO, E. A.; BARROZO, L. M. Estresse salino e temperaturas na germinação e vigor de sementes de Chorisia glaziovi O. Kuntze. Revista Brasileira de Sementes, Londrina, v. 33, n. 2, p. 279- 288, 2011.

KASHEM, M. A.; SULTANA, N.; IKEDA, T.; HORI, H.; LOBODA, T.; MITSUI, T. Alteration of starchsucrose transition in germinating wheat seed under sodium chloride salinity. Journal of Plant Biology, Springer, v. 43, n. 3, p. 121-127, 2000. http://dx.doi.org/10.1007/BF03030488

LIMA, B. G.; TORRES, S. B. Estresses hídrico e salino na germinação de sementes de Zizyphus joazeiro Mart. (Rhamnaceae). Revista Caatinga, Mossoró, v. 22, n. 4, p. 93-99, 2009.

LIMA, M. F. P.; PORTO, M. A. F.; TORRES, S. B.; FREITAS, R. M. O.; NOGUEIRA, N. W.; CARVALHO, D. R. Emergência e crescimento inicial de plântulas de albízia submetidas à irrigação com água salina. Revista Brasileira de Engenharia Agrícola e Ambiental, v.19, n.1, p.3-8, 2015.

MAYER, A. C.; POLJAKOFF-MAYBER, A. The germination of seeds. London: Pergamon Press, 1989. 270p.

MIRANDA, J. R. P.; CARVALHO, J. G.; FERNANDES, A. R.; PAIVA, H. N. Produção de massa seca e acúmulo de nutrientes por plantas de moringa (Moringa oleifera Lam.) cultivadas em solução nutritiva com diferentes níveis de NaCl. Revista de Ciências Agrárias, Belém, v. 47, p. 187-198, 2007.

MUNNS, R. Comparative physiology of salt and water stress. Plant, Cell and Environment, Oxford, v. 25, p. 239-250, 2002. http://dx.doi.org/10.1046/j.0016-8025.2001.00808.x

NOGUEIRA, N. W.; LIMA, J. S. S.; FREITAS, R. M. O.; RIBEIRO, M. C. C.; LEAL, C. C. P.; PINTO, J. R. S. Efeito da salinidade na emergência e crescimento inicial de plântulas de flamboyant. Revista Brasileira de Sementes, Londrina, v. 34, n. 3, p. 466-472, 2012.

OLIVEIRA, A. M.; LINHARES, P. C. F.; MARACAJÁ, P. B.; RIBEIRO, M. C.; BENEDITO, C. P. Salinidade na germinação e desenvolvimento de plântulas de aroeira (Myracroduon urundeuva FR All). Revista Caatinga, Mossoró, v. 20, n. 2, p. 39-42, 2007.

OLIVEIRA, F. R. A.; OLIVEIRA, F. A.; GUIMARÃES, I. P.; MEDEIROS, J. F.; OLIVEIRA, M. K. T.; FREITAS, A. V. L.; MEDEIROS, M. A. Emergência de plântulas de moringa irrigada com água de diferentes níveis de salinidade. Bioscience Journal, Uberlândia, v. 25, n. 5, p. 66-74, 2009.

OLIVEIRA, I. R. S.; OLIVEIRA, F. N.; MEDEIROS, M. A.; TORRES, S. B.; TEIXEIRA, F. J. V. Crescimento inicial do pinhão-manso (Jatropha curcas L.) em função da salinidade da água de irrigação. Revista Caatinga, Mossoró, v. 23, n. 4, p. 40-45, 2010.

RIBEIRO, M. C. C.; BARROS, N. M. S.; BARROS JÚNIOR, A. P.; SILVEIRA, L. M. Tolerância do sabiá (Mimosa caesalpiniaefolia Benth.) à salinidade durante a germinação e o desenvolvimento de plântulas. Revista Caatinga, Mossoró, v. 21, n. 5, p. 123-126, 2008.

SILVA, L. B.; SANTOS, F. A. R.; GASSON, P.; Cutler D. Estudo comparativo da madeira de Mimosa ophthalmocentra Mart. ex Benth. e Mimosa tenuiflora (Willd.) Poir. (Fabaceae-Mimosoideae) na caatinga nordestina. Acta Botânica Brasílica, Feira de Santana, v. 25. n. 2, p. 301-314, 2011.

SILVA, M. B. R. BATISTA, R. C.; LIMA, V. L. A.; BARBOSA, E. M.; BARBOSA, M. F. N. Crescimento de plantas jovens da espécie florestal favela (Cnidosculus phylla-canthus Pax \& K. Hoffm) em diferentes níveis de salinidade da água. Revista de Biologia e Ciências da Terra, Campina Grande, v. 5, n. 2, p. 1-13, 2005. 
SIVRITEPE, N.; SIVRITEPE, H. O.; ERIS, A. The effect of $\mathrm{NaCl}$ priming on salt tolerance in melon seedling grown under saline conditions. Scientia Horticulturae, Frankfurt, v. 97, p. 229-237, 2003. http://dx.doi.org/10.1016/S0304-4238(02)00198-X

SOUZA FILHO, A. P. S. Influência da temperatura, luz e estresses osmótico e salino na germinação de sementes de Leucaena leucocecephala. Pasturas Tropicales, Cali, v. 22, n. 2, p. 47-53, 2000. 